\title{
"A Mountain in an Open Field": Symbolism of Mountains and Fields in the Russian Linguaculture
}

\section{Abramova Veronika Igorevna ${ }^{1}$}

Associate Professor, L.N. Tolstoy Tula State Pedagogical University

Tula, Russia.

\section{Arkhangelskaya Juliya Vladimirovna ${ }^{2}$}

Principal Research Scientist, L. N. Tolstoy Tula State Pedagogical University

Tula, Russia

(date of receiving: October, 2020; date of acceptance: November, 2020)

\begin{abstract}
A Mountain and a field are universal cultural symbols which naturally fit into the Russian lingual world picture. Being the dimensional measures (a mountain - in vertical direction, a field - in horizontal direction), they are at the same time opposed to each other (as flatness and prominence) and look alike (in their scales). The symbolic meanings of a mountain and a field in the Russian linguaculture can be divided into opposed, coinciding and being beyond comparison. Opposition is presented by $a$ mountain - predominantly negative locus not explored by man, the symbol of the stronghold, the obstacle, and a field - the positive cultivated space, the symbol of unrestricted scope, freedom. The coinciding symbolic meanings of a mountain and $a$ field are the following: the border between worlds; locus where gods or demons dwell; surreal space; alien, dangerous place. Beyond comparison are such symbolic meanings as for a mountain - place of merging of the sky and the land; the kingdom of the dead; grief; fate; path of life; a great amount of something; grave state of mind; for a field the motherland; community with the Russian people; fertility; place of a battle; locus of wonders.
\end{abstract}

Keywords: Russian Linguaculture, Symbolic Meaning, Mountain, Field, Space.

1. E-mail: istinijobraz@mail.ru

2. E-mail: archangelju@yandex.ru 


\title{
«В чистом поле - гора»: символика горы и поля в русской лингвокультуре
}

\author{
Абрамова Вероника Игоревна ${ }^{1}$
}

Доцент, Тульский государственный педагогический университет им. Л. Н. Толстого, Тула, Россия.

\section{Архангельская Юлия Владимировна ${ }^{2}$}

Старший научный сотрудник, Тульский государственный педагогический университет им. Л. Н. Толстого

Тула, Россия.

(дата получения: октябрь 2020 г.; дата принятия: ноябрь 2020 г.)

\section{Аннотация}

Гора и поле - универсальные культурные символы, естественно вписывающиеся в русскую языковую картину мира. Являясь пространственными мерами (гора - по вертикали, поле - по горизонтали), они одновременно противопоставлены друг другу (как выпуклость и плоскость) и похожи (по своим масштабам). Символьные значения горы и поля в русской лингвокультуре можно разделить на противопоставленные, совпадающие и находящиеся вне сопоставления. Оппозицию представляют собой гора - преимущественно отрицательный, не освоенный человеком локус, символ твердыни, преграды и поле - положительное окультуренное пространство, символ неограниченного простора, воли. Совпадающими символьными значениями горы и поля являются следующие: граница между мирами; локус, где обитают боги или демоны; ирреальное пространство; чужое, опасное место. Вне сопоставления оказываются такие символьные значения, как место соединения неба и земли; царство мертвых; горе; рок; жизненный путь; большое количество чего-либо; тяжелое душевное состояние - у горы; Родина; общность с русским народом; плодородие; место битвы; локус чудес - у поля.

Ключевые слова: Русская Лингвокультура, Символьное Значение, Гора, Поле, Пространство.

1. E-mail: istinijobraz@mail.ru

2. E-mail: archangelju@yandex.ru

Исследование выполнено при поддержке Российского фонда фундаментальных исследований (грант № 19-512-18008). Название проекта: «Символика русских и болгарских вербальных текстов культуры». 


\section{Введение}

Гора и поле являются особыми символическими локусами в русской лингвокультуре. С одной стороны, они вписаны в мировой контекст, представляют собой культурные универсалии. В составленном профессором А. Ф.Журавлевым списке минимальных смыслов, которые вовлечены в мифологические сюжетные мотивы, частотность употребления единиц гора и поле составляет 409 и 62 соответственно (Журавлев 2016. 19-20). Эти данные можно объяснить, с нашей точки зрения, тем, что символика поля является актуальной для земледельческих культур, а символика горы - для всех народов, поскольку гора - более древний культурный символ. По этой же причине лексема гора входит в так называемый список Сводеша (набор базисной лексики, с помощью которого можно оценивать степень родства между языками), а лексема поле в нем отсутствует (Kassian and other 2010).

Гора в мировой культуре воспринимается как модель вселенной, центральная ось. «На ее вершине обитают боги, под горой (или в ее нижней части) - злые духи, принадлежащие к царству смерти, на земле (посередине) человеческий род» (Топоров 1987. 311). Горы как реальные географические объекты почитались, обожествлялись и дублировали мировую гору в мифологиях и религиозных системах разных народов (Топоров 1978. 312): Фудзияма в Японии, Олимп в Греции, Броккен в Германии, Арафат в мусульманстве, Фавор в христианстве и др.

Поле для земледельческих культур является источником пищи, следовательно, жизни, поэтому символически соотносится с ее зарождением, течением и прекращением. Поле мыслится одновременно и как освоенное, культурное пространство, и как пространство чужое, опасное, и как граница между ними. У многих народов существуют представления о духах поля, враждебных или дружественных по отношению к человеку. 
С другой стороны, несомненно, важное значение горы и поля для славянской, в частности, русской картины мира, что отражено в языке. Эти лексемы выступают в качестве языковых символов (Телия 1996. 243), транслирующих важные для нации культурные смыслы.

\section{Основная часть}

Гора в русской лингвокультуре имеет следующие символьные значения:

1) Место соединения неба и земли. Отсюда двойственность символики.

Положительная символика - место пребывания богов, место силы: горе́ вверх, горний - верхний. Горнее место в храме. «Горе душа летит» [В.А. Жуковский. Невыразимое (1819), НКРЯ]. «И внял я неба содроганье, / И горний ангелов полет» [А.С. Пушкин. Пророк (1826), НКРЯ].

Отрицательная символика - место пребывания демонов, нечистой силы. Горной (рус., урал.) - нечистый дух, обитающий в шахтах. Хозяйка Медной горы (фигурирует в сказах П.П. Бажова, дух - хранитель горных сокровищ). Лысая гора (место сборища ведьм). Змей Горыныч (сказочный персонаж, выступающий в роли вредителя).

2) «Тот свет», царство мертвых. Отправиться на горку - умереть. Гора (костр.) - кладбище, располагаемое на пригорке (Даль 2000. 183). Мыльная гора (тул.) - кладбище, отправиться на Мыльную гору - умереть. В старину вторник второй недели после Пасхи именовался красной горкой и являлся днем поминовения усопших: В красную горку родители из могиль теплом дохнут (Даль 1912. Стлб. 928)

3) Печаль, горе (в народной лирике): «Bетры мои, ветры, вы буйные ветры! / Не можете ли ветры, горы раскачати? / Гусли мои гусли, звончатые гусли! / Не можете ли вы, гусли, вдову взвеселити?»; «Уж вы, горы мои, горы Воробьевские, / Ничего вы, горы, ничего не 
породили, / Породили горы один бел-горюч камень» (Лирические народные песни 1955. 67, 344).

4) Нечто незыблемое, не сдвигаемое с места, трудноодолимое: Гора с горой не сходится, а человек с человеком сойдется - говорится при неожиданной встрече (Михельсон 1902-1903. Т.1, 208); Как на каменную гору (надеяться, полагаться на кого-либо) - вполне, целиком (надеяться, полагаться) (ФСРЯ 1967. 118).

5) Нечто фундаментальное: своротить горы (гору) - делать большое дело, требующее огромных усилий (ФСРЯ 1967. 79), горами двигать - совершать большие важные дела. «А всем известно, что если народ соответствующим образом вдохновить, он способен горы свернуть» [Константин Серафимов. Экспедиция во мрак (1978-1996), НКРЯ].

6) Трудности, трудная работа: В гору-то семеро тащат, а с горы $u$ один столкнет. С горы вскачь, а в гору - хоть плачь. Укатали сивку крутые горки (Даль 1957. 519, 494, 276, 506). «Сейчас не осталось сил даже для мечтаний и для воображения; поэтому я не могу себе представить ни маму, ни Вас, ни городских улии, ничего. Укатали сивку крутые горки. Очень Вас прошу, пишите хоть открытки, nусть пустые» [Эмма Герштейн. Анна Ахматова и Лев Гумилев (1994-2002), НКРЯ].

7) Рок, фатум: И крута гора, а миновать нельзя (Михельсон 1902 1903, T.1, 369).

8) Жизненный путь вообще или жизненное поприще, на котором можно преуспеть: Идти (лезть, переть) в гору - «1. Приобретать вес, значение; делать карьеру. О человеке. 2. Развиваться в благоприятном направлении, успешно. О чем-либо» (ФСРЯ 1967. 181) Идти под гору - «1. Развиваться в неблагоприятном 
направлении; резко ухудшаться. 2. Близиться к концу. О жизни» (ФСРЯ 1967. 182). «И не только уцелел - в гору пошел, стал начальником Томского НКВД 15» [А. И. Солженицын. Архипелаг ГУЛаг (1958-1973), НКРЯ].

9) Большое количество чего-либо. Золотые (златые) горы «сказочное богатство, благополучие и т.п. (обещать, сулить комулибо) (ФСРЯ 1967. 118): «Словом, обещуает ей золотые горы, подводит к своей жене и дочери, те тоже восхищаются её голосом, тоже уговаривают ехать в Петербург, тоже сулят золотые горы, жить она будет у них, ни в чём не будет нуждаться, станет знаменитой певицей» [Анатолий Рыбаков. Тяжелый песок (1975-1977), НКРЯ].

10) Тяжелое душевное состояние: гора (лежит) на душе - «о тягостном душевном состоянии, о тяжелых заботах» (ФСРЛЯ 1997. Т. 1. 155); гора с плеч свалилась - «рассеялись тревоги, сомнения; наступило полное облегчение после избавления от забот, обязанностей, от чего-либо обременительного и т.п.» (ФСРЯ 1967. 116). «Только начал эту фразу, как принесли твое письмо, и у меня гора с плеч свалилась!» [Александр Морозов. Прежние слова (19852001) // «Знамя», 2002, НКРЯ].

11) Пространственная или временная граница: $3 a$ горами - далеко. Дума за горами, а смерть за плечами. Не за горами - «1. Неподалеку, очень близко (находиться, быть и т.п.). 2. Скоро, в ближайшем будущем наступит, произойдет и т.п. что-либо» (ФСРЯ 1967. 116). «Он понимал и то, что теперь его собственный конец не за горами, но и это совершенно его не трогало» [Ю. О. Домбровский. Факультет ненужных вещей, часть 3 (1978), НКРЯ]. 
12) Ирреальный локус. На кудыкину гору - «ответ на вопрос “Куда идешь?” при нежелании отвечать». По одной из версий, возникло в народной речи из созвучия наречия куда с утраченным теперь существительным куд (злой дух, дьявол) (Бирих, Мокиенко, Степанова 1999. 127). «Куда, куда? Да на кудыкину гору! - дерзко отвечает Вася Некрасов, нескладный долговязый парень с кудрявой, как у Калмановича, только русой головой» [Алексей Моторов. Преступление доктора Паровозова (2013), КНРЯ]. Примечательно, что вариантом ответа на вопрос «Куда?» является устойчивая единица на кудылино поле. Это свидетельствует о семантической и символической близости локусов гора и поле в русской лингвокультуре: «Григорий поиграл зарозовевшими желваками скул, но ответил весело, с подмигом: - На кудыкино поле. Понял? И вымел» [М. А. Шолохов. Тихий Дон. Книга третья (1928-1940), НКРЯ].

Поле в русской лингвокультуре имеет следующие символьные значения:

1) Бесконечность, открытость: чистое поле. О власти пространств над русской душой писал философ Н.А. Бердяев: «Русская душа подавлена необъятными русскими полями и необъятными русскими снегами, она утопает и растворяется в этой необъятности» [Н. А. Бердяев. О власти пространств над русской душой (19141918), НКРЯ]. Литератор Д. В. Григорович отмечал: «Тут узнаете вы жизнь народа; тут только увидите настоящее русское поле, с тем необъятно-манящци простором, о котором так много уже сльишали и так много, быть может, мечтали» [Д. В. Григорович. Пахарь (1856), НКРЯ].

2) Абсолютное пространство, равное земле или небу: «Стану я, раба Божья, благословесь, пойду перекрестесь из ызбы дверями, из 
ворот воротами, выйду я в цүисто полё. В цุистом поли Окиян синё море, в Окияни синём мори бел остроф, на билу острову Лип камень, на Липу камню сидит Олёна царевна...» (цит. по: Славянские древности 2009. 134); «Поле не меряно, овщ̧ь не считаны, nacmух рогат» (загадка о небе, звездах и месяце, цит. по: Славянские древности 2009. 134).

3) Русская земля, Родина. Как отмечают исследователи, топос поля становится в русской традиции этническим символом, на уникальность которого указывает тот факт, что понятие «поле» не может быть адекватно переведено на неславянские, в частности, английский, языки, является для британского языкового сознания когнитивной лакуной (Аликаев, Чуликов 2010. 145). Данное символьное значение поддерживается в русской лирике: «O Pycb, малиновое поле / И синь, упавшая в реку, / Люблю до радости и боли / Твою озерную тоску» [С. А. Есенин. «Запели тесаные дроги...» (1916), НКРЯ]. Возникает фольклорно-литературный образ русского поля, который является не только символом русской земли, но и русского национального характера: «Ведь наше русское поле тем и отличается от всех остальных, что на нем нет затейливых ияветов, а только простые васильки да солнечный жолтяк» [П. П. Бажов. Отслоения дней (1944-1947), НКРЯ]; «Скольких, скольких в тайне сжигает полевая мечта; о, русское поле, русское поле!» [Андрей Белый. Серебряный голубь (1909), НКРЯ]; «О Родина, / Мое русское поле, / И вы, сыновья ее, / Остановившие / На частоколе / Луну и солнце, / - Хвалите Бога!» [С. А. Есенин. Певущий зов (1917), НКРЯ]; «Русское поле, березы это то, по чему наш человек скучает на чужбине» [«Спартаку» пора менять дорогу!» // Советский спорт, 2008.03.25, НКРЯ]. 
4) Общность с русским народом, нацией или со своим кругом, людьми, имеющими сходные взгляды на жизнь. «Здравствуй, русское поле, / Я твой тонкий колосок», эта цитата из широко известной песни, написанной в 1968 году композитором Я. Френкелем на стихи И. Гофф для кинофильма режиссера Э. Кеосаяна «Новые приключения неуловимых», перекликается с народными устойчивыми выражениями: Что я в поле за обсевок? (Даль, Пословицы, с. 191), И я в поле не обсевок (Даль, Словарь, т. 2, стлб. 1605), то есть не хуже других, такой же, как все, суть которых в следующем: если человек ассоциирует себя с обсевком (незасеянным клочком поля), то это говорит о том, что он одинок, разобщен с народом (оставлять незасеянными даже небольшие участки поля считалось очень плохой приметой, сулило несчастья). Ср. также: Намего поля ягода; Не нашего поля ягода; Не на том поле трава выросла (Даль 1912-1914. Т. 3, стлб. 647).

5) Воля. Многие исследователи отмечают «взаимное символическое и семантическое притяжение поля (как бесконечного и недискретного пространства) и воли (как ничем не ограниченной свободы), поддерживаемое в песнях рифмой...» (Славянские древности 2009. 134). Кроме того, рифма поле - воля часто используется в русских пословицах: «B поле воля», «В чистом поле четыре воли: хоть туда, хоть сюда, хоть инаково», «Жить по воле, умереть в поле», «Не верь ветру в поле, а жене в воле», «Взяли волю: едем по всему полю» (Даль 1957. 834, 835, 841, 842).

6) Плодородие. Засеянное поле - древний славянский, в том числе и русский, символ. Он эмблематически поддержан узором традиционной вышивки, очень часто использовавшейся в старину для украшения женской одежды, являясь знаком не только плодородия земли, но и женского плодородия. Как языковой 
символ плодородия поле часто употребляется в пословицах: Что в поле ни родится, все в доме пригодится (Там же. 594); Красно поле рожью, а речь ложью (то есть красным словцом) (Там же. 201), В поле пшеница годом родится, а добрый человек всегда пригодится (Там же. 776), а также в формулах речевого этикета (приветствиях, пожеланиях, поздравлениях с урожаем или, напротив, в устойчивых выражениях, содержащих брань, проклятие): $C$ двумя полями сжатыми, с третьим засеянным (поздравление в пожинках) (Там же. 752), Как в поле трава растет, так бы твое добро росло (говорит отец, благословляя и оделяя сына, что всегда делается в новолуние) (Даль 1957. 388); В поле тебе лебеды, да в дом три беды (Там же. 750). Таким образом, поле является знаком важного для существования русского человека места: поле кормит человека, в поле родится хлеб, который дает возможность жизни в течение целого года.

7) Граница между своей и чужой землей: дикое поле (пространство между Доном и левыми притоками Днепра и Десны, которое разделяло лес и степь, земледельцев и кочевников), поле половецкое (этнотопоним из «Слова о полку Игореве», обозначающий владения половцев).

8) Чужое пространство. В русских заговорах в поле изгоняли домашних насекомых: «Bот я, раба Божия (и.р.), указываю вам, клопам, путь-дорогу, идите все поездом по всем путям, по тропинам во чистые поля, во глубокие моря - у нас не живите никогда» (цит. по: Славянские древности 2009. 136). По русским поверьям в поле живет полевик (житный дед, гречуха) - дух, охраняющий хлебные поля, однако человеку он может вредить, поэтому его задабривают различными подношениями. 
9) Место битвы: поле брани, ратное поле, Куликово поле, Бородинское поле, поле русской славы. Символьное значение поля как места, где происходит встреча противостоящих друг другу сил, поддерживается в пословицах: «Один в поле не воин», «Солдат умирает в поле, матрос в море» (Даль 1957. 631, 834). Метафора битвы как пахоты, сева и жатвы, широко распространенная в фольклоре и древнерусской литературе, также связана с этим символьным значением: «Не плугами поле, не сохами поле распахано, / А распахано поле конскими копытами, / Засеяно поле не всхожими семенами, / Засеяно казачьими головами, / Заволочено поле казачьими черными кудрями» (цит. по: Славянские древности 2009. 134); «На Немизе снопы стелютъ головами, молотять чепи харалужными, на тоце животь кладуть, веють душу оть тела. Немизе кровави брезе не бологомь бяхуть посеяни, посеяни костьми Рускихъ сыновъ» (Слово о полку Игореве 1985. 34, 45).

10) Поле нередко присутствует в устойчивых формулах определенных фольклорных жанров, а именно - загадках и сказочных зачинах, являясь знаком ирреального пространства: «B чистом поле, 6 широком раздолье, за темными лесами, за зелеными лугами, за быстрыми реками, за крутыми берегами» (сказочная устойчивая формула); «Широко поле карагайское, на нем много скота тараканского, один пастух, ровно ягодка» (загадка; отгадка звезды, месяц) и др. под. (Даль 1912-1914. Т.3, стлб. 647-648). В качестве эпитетов к полю в загадках употребляются слова арекское, ногайское, карагайское, колыбанское, ордынское, сиянское, титенское $u$ др., призванные, как может показаться на первый взгляд, конкретизировать определяемое слово, но не позволяющие, однако, соотнести поле с определенным локусом. Из этого можно сделать вывод о том, что включенность слова поле в подобные 
словесные комплексы поддерживает символьное значение ирреального пространства.

11) Локус чудес. В русских сказках («Морской царь и Василиса Пермудрая») поле за одну ночь обрабатывают (вспахивают, боронят, сеют пшеницу, жнут ее). В сказке А. Н. Толстого «Золотой ключик, или Приключения Буратино» (литературной обработке сказки Карло Коллоди «Приключения Пиноккио. История деревянной куклы») фигурирует Поле Чудес, на котором заглавный герой зарывает пять золотых монет в надежде вырастить денежное дерево. Поддержанное названием популярной российской телеигры выражение «поле чудес» стало устойчивым в русском языке: так называются компьютерные игры, реальные географические объекты (район на территории города Бузулука в Оренбургской области, историческая местность на левом берегу реки Пехорка на территории города Балашиха, остановки общественного транспорта в этом районе, база отдыха в Тюменской области). В «Большом словаре русских поговорок» зафиксировано несколько значений устойчивой единицы поле чудес, которая употребляется в разговорной речи и жаргонах: 1) плац, 2) стрельбище, 3) школьный двор, 4) последняя парта, 5) Советский Союз (Большой словарь русских поговорок). В Национальном корпусе русского языка присутствуют примеры употребления устойчивого выражения поле чудес в следующих значениях: 1) пространство абсурда («Солдатская столовая - поле чудес... Два года: каша, квашеная капуста и макароны, суп из мяса, которое хранили на военных складах на случай войны» [Светлана Алексиевич. Время secondhand // «Дружба народов», 2013, НКРЯ]); 2) призрачная надежда быстро и без труда обогатиться («Поверь, это чистая правда! «Роснефть» - это поле чудес! Впрочем, главный экономист Альфа- 
банка Наталья Орлова уверена, что никакой кризис не отобьет у населения желание вкладывать деньги в акиии» [Руслан Хестанов. Как пережить кризис // «Русский репортер», № 3 (33), 31 января - 7 февраля 2008, НКРЯ]); 3) ироничное разговорное название района, где живут богатые люди («Это - местная Рублевка, которую здесь, как и в большинстве провинциальных городов, называют «Долина нищих» или «Поле чудес» [Юлия Вишневецкая. Почему Россия - не Москва // «Русский репортер», № 43 (122), 12-19 ноября 2009]).

С одной стороны, представляется очевидным противопоставление в русской лингвокультуре горы и поля как языковых символов. Действительно, если гора - это в первую очередь вертикаль, некая твердыня, неприступная преграда, знак трудностей в жизни и судьбе, то поле - это прежде всего горизонталь, простор, устойчиво ассоциирующийся в русском сознании с раздольем и волей (ничем не ограниченной свободой). При этом символьные значения горы имеют преимущественно отрицательные коннотации, тогда как поле чаще является знаком чего-либо положительного.

С другой стороны, анализируемые языковые символы имеют немало общего. Несомненно, и гора и поле в русской лингвокультуре - это локусы силы. Являясь знаками границы между мирами, они символизируют двоемирие, где может преобладать как божественное, так и демоническое. Как видно из предшествующего анализа, и гора и поле могут символизировать прибежище нечистой силы, чужое опасное пространство, но также могут обозначать место пребывания богов (гора) или место явления божественного промысла (поле). Так, в старину перед сражением в поле происходил поединок двух воинов - по одному от каждой из враждебных армий: $B$ поле две воли: кому Бог поможет. Считалось, что армию победителя в бою будет поддерживать Бог. Вспомним также старинную традицию судебных 
поединков, происходящих в поле: «А досудятся до поля (т.е. коли тяжбу решить более нечем, как полем, Божьим судом), да не став у поля помирятся (судебн.), В поле съезжаются, так родом не считаются; На поле Никола общий бог; Кому на поле Божья помощьь» (Даль 1912-1914. Т. 3, стлб. 648).

Кроме того, в фольклорных и литературных текстах гора и поле нередко встречаются в одном и том же фрагменте, например в пословице: Не пришлось поле ко двору - пускай его под гору (Там же. стлб. 647). В сказках гора и поле могут символизировать огромные пространства, которые отделяют героя от цели и которые ему предстоит преодолеть на пути к счастливой развязке: «Шла она чистым полем, ила темным лесом, высокими горами» («Финист ясный сокол»). Употребляясь в одном контексте в заговорах, гора и поле являются знаками важных пространственных локусов, мифологических центров: «В чистом поле стоит свякоська гора»; «Выйду в чистое поле, в чистоем поле - гора бошовинска» (Цит. по: Агапкина, Березович, Сурикова 2018. 38, 46). В знаменитом произведении М.В. Ломоносова «Ода на день восшествия на Всероссийский престол Ее Величества Государыни Императрицы Елисаветы Петровны 1747 года» горы и поля символически обозначают обширность русской земли, которой владеет государыня: «Воззри на горы превысоки, / Воззри в поля твои широки» (Ломоносов 1986. 118).

\section{Заключение}

Проведенный анализ показал следующее.

1. Гора и поле являются важными символами в русской лингвокультуре прежде всего потому, что обозначают локусы силы, которая может быть как со знаком плюс, так и со знаком минус.

2. Гора символизирует место соединения неба и земли; «тот свет», царство мертвых; печаль, горе (в народной лирике); нечто незыблемое; нечто фундаментальное; трудности; рок, фатум; жизненный путь или жизненное 
поприще; большое количество чего-либо; тяжелое душевное состояние; пространственную или временную границу; ирреальный локус.

3. Поле в русской лингвокультуре имеет следующие символьные значения: бесконечность, открытость; абсолютное пространство, равное небу и земле; Русская земля, Родина; общность с русским народом; плодородие; воля, раздолье; граница между своей и чужой землей; чужое пространство; место битвы (в том числе место проявления Божественного промысла во время поединков); ирреальное пространство; локус чудес.

4. Символы горы и поля в русской лингвокультуре противопоставлены друг другу по нескольким параметрам: во-первых, горе как символу твердыни, неприступной преграды противостоит поле, являющееся знаком раздолья, воли, ничем не ограниченной свободы; во-вторых, большинство символьных значений горы имеют отрицательные коннотации, тогда как поле чаще является знаком чего-либо положительного; в-третьих, основная часть символьных значений горы характеризует данный локус как дикий, неосвоенный, в то время как поле прежде всего символизирует земледельчески освоенное место.

5. Символика горы и поля в русской лингвокультуре имеет и немало общих черт: эти слова символизируют границу между мирами; двоемирие, где может преобладать как положительное, так и отрицательное начало; ирреальное пространство; чужое, опасное место. При использовании в одном контексте горы $u$ поля могут служить знаком дальнего расстояния, обширных пространств.

\section{Литература}

1- Агапкина Т. А., Березович Е. Л., Сурикова О. Д. (2018). Топонимия заговоров русского севера. II: Земли. Горы. Острова. Города // Вопросы ономастики. Т. 15. № 2. C. 28-69. 
2- Аликаев Р.С., Чуликов Ю. М. (2010). Локусы «чужого» пространства в фольклорной модели мира (на материале русской и британской лингвокультур) // Вестник Северо-Осетинского государственного университета им. К. Л. Хетагурова. № 2. С. 142-146.

3- Бирих А. К., Мокиенко В. М., Степанова Л. И. (1999). Словарь русской фразеологии. Историко-этимологический справочник. Санкт-Петербург. Фолио-Пресс.

4- Большой словарь русских поговорок (2007). URL: http://rusyaz.niv.ru/doc/russian-sayings/articles/61/pole.htm (дата обращения: 25.09.20).

5- Даль В. И. (1957). Пословицы русского народа. Москва. Государственное издательство художественной литературы.

6- Даль В. И. (1912-1914). Толковый словарь живого великорусского языка. В 4 $m$., Санкт-Петербург - Москва. Издание товарищества М.О. Вольф.

7- Даль В. И. (2000). Толковый словарь русского языка. Современная версия. Москва. ЗАО Издательство ЭКСМО-Пресс.

8- Жравлев А. Ф. (2016). Эволючии смыслов. Москва. Издательский Дом ЯСК.

9- Лирические народные песни (1955). Ленинград. Библиотека поэта. Малая серия.

10- Ломоносов М. В. (1986). Избранные произведения. Ленинград. Советский писатель.

11- Михельсон М. И. (1902-1903). Русская мысль и речь: Свое и чужое. Oпыт русской фразеологии. Сборник образных слов и иносказаний. В 2 т. СанктПетербург. Типография Академии Наук.

12- Национальныий корпус русского языка. URL: https://ruscorpora.ru/new/searchmain.html (дата обращения: 31.08.20).

13- Славянские древности (2009). Этнолингвистический словарь в 5 т. Т. 4. П - С. Москва. Международные отношения.

14- Слово о полку Игореве (1985) Москва. Художественная литература.

15- Телия В. Н. (1996). Русская фразеология. Семантический, прагматический и лингвокультурологический аспекты. Москва. Языки славянской культуры.

16- Топоров В.Н. (1987). Гора // Мифы народов мира. Москва. Советская энциклопедия.

17- Финист - ясный сокол URL: https://nukadeti.ru/skazki/finist_yasnyj_sokol (дата обращения 30.09.20).

18- ФСРЛЯ - Фразелогический словарь русского литературного языка (1997). В 2 т. / Сост. А. И. Федоров. Москва. Цитадель. 
19- ФСРЯ - Фразеологический словарь русского языка (1967). / под ред. А. И. Молоткова. Москва. Советская энциклопедия.

20- Kassian A., Starostin G., Dybo A., Chernov V. The Swadesh wordlist. An attempt at semantic specification. URL: https://starling.rinet.ru/new100/Swadesh.htm\#_ftn1 (дата обращения: 31.08.20).

\section{Bibliography}

1- Agapkina T. A., Berezovich E. L., Surikova O. D. (2018). Toponimija zagovorov russkogo severa. II: Zemli. Gory. Ostrova. Goroda // Voprosy onomastiki. T. 15. № 2. S. 28-69.

2- Alikaev R. S., Chulikov Ju. M. (2010). Lokusy «chuzhogo» prostranstva v fol'klornoj modeli mira (na materiale russkoj i britanskoj lingvokul'tur) // Vestnik Severo-Osetinskogo gosudarstvennogo universiteta im. K. L. Hetagurova. № 2. S. 142-146.

3- Birih A. K., Mokienko V. M., Stepanova L. I. (1999). Slovar' russkoj frazeologii. Istoriko-jetimologicheskij spravochnik. Sankt-Peterburg. Folio-Press.

4- Bol'shoj slovar' russkih pogovorok (2007). URL: http://rus-yaz.niv.ru/doc/russiansayings/articles/61/pole.htm (data obrashhenija: 25.09.20).

5- Dal' V. I. (1957). Poslovicy russkogo naroda. Moskva. Gosudarstvennoe izdatel'stvo hudozhestvennoj literatury.

6- Dal' V. I. (1912-1914). Tolkovyj slovar' zhivogo velikorusskogo jazyka. V 4 t., Sankt-Peterburg - Moskva. Izdanie tovarishhestva M.O. Vol'f.

7- Dal' V. I. (2000). Tolkovyj slovar' russkogo jazyka. Sovremennaja versija. Moskva. ZAO Izdatel'stvo JeKSMO-Press.

8- Zhuravlev A. F. (2016). Jevoljucii smyslov. Moskva. Izdatel'skij Dom JaSK.

9- Liricheskie narodnye pesni (1955). Leningrad. Biblioteka pojeta. Malaja serija.

10- Lomonosov M. V. (1986). Izbrannye proizvedenija. Leningrad. Sovetskij pisatel'.

11- Mihel'son M. I. (1902-1903). Russkaja mysl' i rech': Svoe i chuzhoe. Opyt russkoj frazeologii. Sbornik obraznyh slov i inoskazanij. V 2 t. Sankt-Peterburg. Tipografija Akademii Nauk.

12- Nacional'nyj korpus russkogo jazyka. URL: https://ruscorpora.ru/new/searchmain.html (data obrashhenija: 31.08.20).

13- Slavjanskie drevnosti (2009). Jetnolingvisticheskij slovar' v 5 t. T. 4. P-S. Moskva. Mezhdunarodnye otnoshenija.

14- Slovo o polku Igoreve (1985) Moskva. Hudozhestvennaja literatura. 
15- Telija V. N. (1996). Russkaja frazeologija. Semanticheskij, pragmaticheskij $i$ lingvokul'turologicheskij aspekty. Moskva. Jazyki slavjanskoj kul'tury.

16- Toporov V. N. (1987). Gora // Mify narodov mira. Moskva. Sovetskaja jenciklopedija.

17- Finist - jasnyj sokol URL: https://nukadeti.ru/skazki/finist_yasnyj_sokol (data obrashhenija 30.09.20).

18- FSRLJa - Frazelogicheskij slovar' russkogo literaturnogo jazyka (1997). V 2 t. / Sost. A. I. Fedorov. Moskva. Citadel'.

19- FSRJa - Frazeologicheskij slovar' russkogo jazyka (1967). / pod red. A. I. Molotkova. Moskva. Sovetskaja jenciklopedija.

20- Kassian A., Starostin G., Dybo A., Chernov V. The Swadesh wordlist. An attempt at semantic specification. URL: https://starling.rinet.ru/new100/Swadesh.htm\#_ftn1 (data obrashhenija: 31.08.20).

\section{HOW TO CITE THIS ARTICLE}

Абрамова, В., \& Архангельская, Ю. (2021). “А Mountain in an Open Field": Symbolism of Mountains and Fields in the Russian Linguaculture. Issledovatel'skiy Zhurnal Russkogo Yazyka I Literatury, 9(1). 89-107.

DOI: $10.52547 /$ iarll.17.89

URL: https:/www.journaliarll.ir/index.php/iarll/article/view/148 
("كوهى در ميان دشت بى كران)): نمادهاى كوه و دشت در فرهنخشناسى زبان روسى

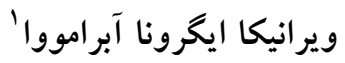

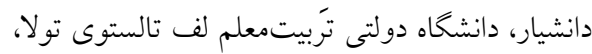

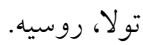

$$
\begin{aligned}
& \text { يوليا ولاديميرونا آرخانگلسكايا؟ }
\end{aligned}
$$

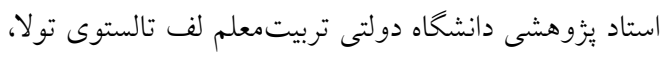

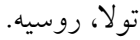

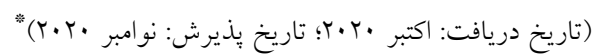

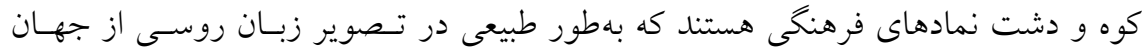

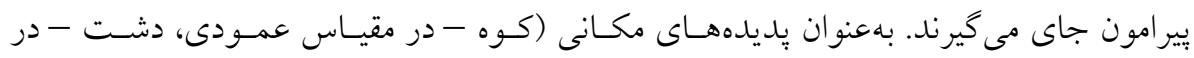

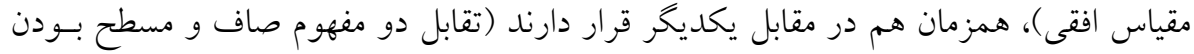

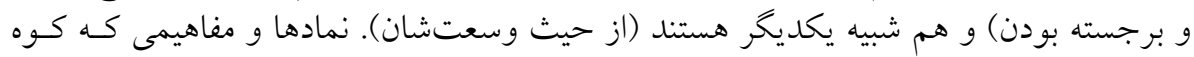

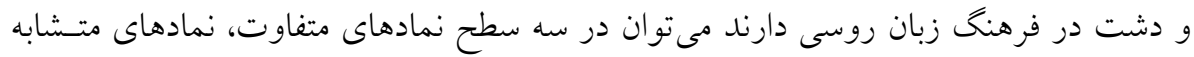

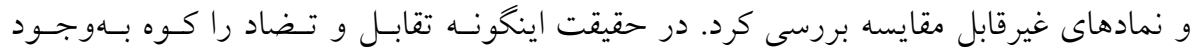

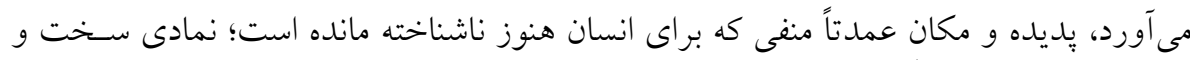

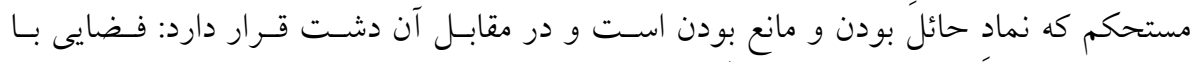

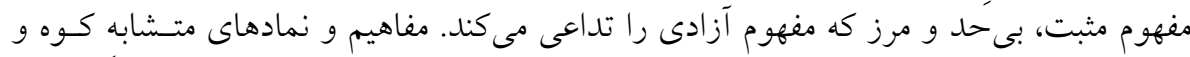

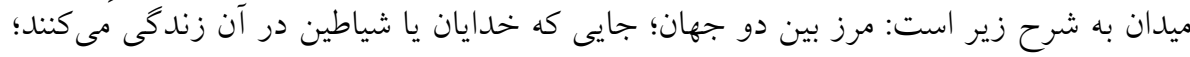

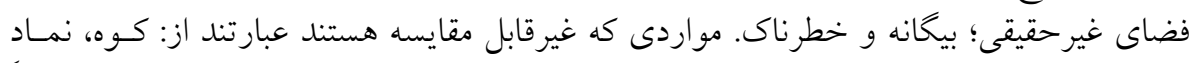

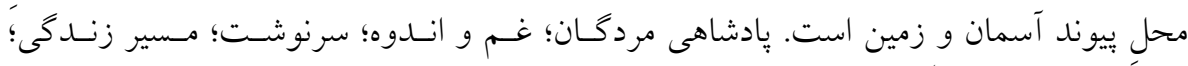

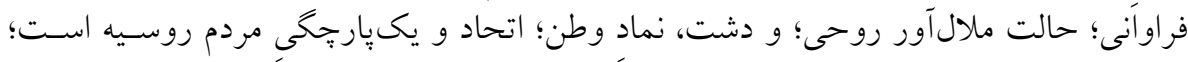

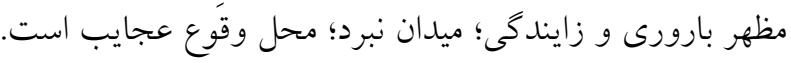

وازگكان كليدى: فرهنگشناسى زبان روسى، مفاهيم نمادين، كوه، دشت، فضا.

1. E-mail: istinijobraz@mail.ru

2. E-mail: archangelju@yandex.ru 